\title{
AN EVALUATION OF THE ARCHITECTURE, CULTURE AND HISTORY \\ OF THE POLONEZKÖY/ADAMPOL SETTLEMENT IN ISTANBUL*
}

\section{INTRODUCTION}

$\Gamma$

Whe Adampol settlement, currently known as Polonezköy, is located in the Beykoz district of Istanbul (Appendix 1). The village was founded in the middle of the 19th century, as a result of historical and political relations between the Ottomans and Poland. Therefore, the historical process of the founding and development of the village should be summarized. ${ }^{1)}$ After having started to deteriorate in the 15th century, Ottoman-Polish relations entered a process of peace with the Treaty of Karlowitz in 1699, primarily due to Russia's increasing power. In 1768, the Ottoman Empire declared war on Russia on the grounds that they had intervened in Polish affairs. In spite of the Ottoman assistance, Polish lands were shared between Prussia, Russia and Austria in 1772. After the split, a number of Polish immigrants came to Istanbul.

The Poles rejected the partition and organized the November Uprising in 1831 to fight a war of independence against Russia. Prince Adam Czartoryski was assigned as the president of the pro-independence National government.

\footnotetext{
* This article was supported by Istanbul University with UDP 8559 (47141) numbered project.

1) This section was compiled from, archived original documents, books and essays written on Polonezköy/Adampol, except where stated. For detailed information, see Adamska (2004); Antonowicz-Bauer (1990); Biskupski (1955: 38-39); Dopierala (2014: 26-35); Latka (1992).
} 
However, the November uprising failed, and the Polish, including President Czartoryski, had to migrate in order not to be killed or exiled to the Russian hinterlands.

Following the uprising in 1831, an organization was founded in France under the leadership of Prince Adam Czartoryski. Named Hotel Lambert, after the Prince's residence, the organization was intended to work towards an independent Polish State and contributed to the foundation of 'the Eastern Mission Main Agency' in Istanbul in 1841. The famous writer Michal Czaykowski was appointed head of the agency.

As soon as he had been assigned, Michal Czaykowski started working on improving the living and legal conditions of Polish refugees in the Ottoman country. To that end, he contacted a congregation of French missionaries, the Lazarists, ${ }^{2)}$ founded by St. Vincent de Paul. It was then suggested that he set up a settlement for Poles in a part of the farms owned by Lazarists, to be managed by Poles according to their own rules. In France, Adam Czartoryski initially disapproved of the idea for economic reasons. However, Prince Adam Czartoryski eventually rented a portion of the land in the Alemdag foothills from the Lazarists. The land intended for the Polish settlement was also called 'the Gypsy Camp' after the gypsies in Istanbul camped there. A map from the early 20th century, which was found in the Ottoman Archive of the Office of the Prime Minister, ${ }^{3)}$ proves the land was called 'the Gypsy Camp' (Appendix 2). The area was actually covered with shrubs and thorn patches; however, the area was found acceptable for settlement because it was located near a forest, and a stream running through it had the capacity to turn a flour mill.

Consequently, Michal Czaykowski and Archpriest Leleu signed a contract on March 3, 1842, and a Polish colony, St. Vincent's Sanctuary, was founded. Czaykowski and Leleu signed the first legislation that specified living conditions in the village on June 30, 1842. The colonial settlement was not only a sanctuary for Polish immigrants in Ottoman lands, but was also regarded as a centre that legalized the presence of 'the Eastern Mission Main Agency' in the Ottoman Empire.

The village was initially scarcely populated. Records from 1842 show only 12 residents, who were soldiers and military officers that had taken refuge in the Ottoman Empire. By 1843, the population of Poles had reached 19. The

2) The congregation was founded in Paris in 1625 and is a religious organization aimed to proselytize Christianity to peasants.

3) BOA, HRT. 0674. 
colony, called St. Vincent's Sanctuary at first, was later named Adam Köy in 1845, after Adam Czartoryski, and Adampol, as a combination of Adam and the first syllable for Poland, in 1846.

A significant development in the history of the village was the Hungarian Uprising named, 'the Spring of Nations', in 1849. When the uprising against the Habsburgs in Hungary was suppressed, a number of Polish soldiers and military officers, who had sought refuge in the Ottoman Empire, were settled in Adampol. Meanwhile, some officers, who Russia had demanded be extradited, converted to Islam and joined the Ottoman army to preserve their freedom. One of these officers, Michal Czaykowski, converted to Islam in 1850, taking the name Mehmet Sadık Pasha and was assigned as the Commander of the Cossack Regiment. Michal Czaykowski's post as the representative of 'the Eastern Mission Main Agency' ended as of that date.

The Ottoman-Russian War, also known as the Crimean War, was important for the village's historical development. In the war between 1854 and 1856, a division under General Zamoyski's command fought in the Ottoman ranks in anticipation of the reconstitution of the Polish State after the defeat of Russia. However, the division disbanded when the Ottoman army was defeated and a number of soldiers and officers of the division had to take refuge in the Ottoman Empire, which allowed Polish soldier refugees to stay in the country and work as farmers and artisans, but required conversion to Islam to take civil service positions. Thirty-eight soldiers directly settled in Adampol after the Crimean War. ${ }^{4)}$

After the uprising of January 1863 in Poland, a number of Polish people that had fled the country defected to the Ottoman Empire. Some of these refugees settled in Adampol and the population of the village reached a hundred in 1863 and a hundred-and-twenty-one after the Russo-Turkish War of 1877-1878. An archived document from 1893, shows a hundred-and-forty Catholic women and men resident in the village. ${ }^{5)}$ Another archived document

4) Sources mention that other village or villages were founded for Polish refugees in the Ottoman Empire after the Crimean War. One source writes about a hundred-and-fifty Polish people, who preferred to work in farming in the Ottoman Empire went to the lands of Mustafa Resit Pasha and founded another Polish village, Reşadiye. Latka (1992: 35-36). Another source writes about a new village named Derbina in the Ottoman Empire after the war, and the village was abandoned in 1859, and the Polish residents were settled in Adampol. Adamska (2004: 6).

5) BOA (Prime Ministry Ottoman Archives), DH. MKT. 6/15; Günalan-Sümbül (2013: 133). 
from 1913, shows a hundred-and-seventy Catholic women and men resident in the thirty-two houses. ${ }^{6)}$ As mentioned above, the Polish village founded in Ottoman lands had certain legal and administrative privileges. For instance, village residents were given the status of French citizens, like the members of 'the Eastern Mission Main Agency' in Istanbul. Furthermore, the land where Polish refugees resided was not initially included in the Ottoman administrative system, but was recorded as a piece of land owned by Prince Czartoyski. ${ }^{7)}$ Polonezköy was separated from the 13th Municipal Office and attached to Beykoz, but no record of the formation of the village was lodged in the Offices of Population or the Imperial Council (Divan-ı Hümayun). ${ }^{8)}$ Adampol's privileged status was rescinded according to provisions of the Second Constitutionalist Period (1908) and the village was made equal to other villages in terms of rights and duties. The village residents were given Ottoman citizenship.9) After World War I, Adampol was generally called 'Polonezköy' rather than 'Adampol'.

The problem concerning ownership of the village land was soon resolved. When Adam Czartoryski, legal leaseholder of the village land, died in 1861, all his rights were transferred to his son, Wladyslaw Czartoryski. In 1880, the land was legally acquired from the Lazarists. When the Czartoryski Family renounced their rights over the land in 1968, village residents were able to obtain their land deeds in 1969.

Naturally, the village, founded as an autonomous agricultural settlement established for Polish refugees in Ottoman lands after the partition of Poland, developed according to the accommodation, religious and social needs of the residents. Polonezköy is currently a tourist attraction and nature centre for domestic tourists. This essay aims to evaluate the cultural heritage of Polonezköy in terms of its history of art and architecture. The foundations of the Catholic Church, school and cemetery, discussed in detail in the essay, were first laid down when the village was established. Written sources and archived documents in the Ottoman Archive in the Office of the Prime Minister, on the construction of the present church and the police station, built in the early 20 th century, were examined in person.

\footnotetext{
6) BOA, ŞD. 2383/5; Günalan-Sümbül (2013: 221).

7) BOA. DH. SN.THR. 18/62_1; Ekinci (2006:254).

8) BOA. İ.DH.1306 /5 (1311. M /5); DH. MKT. 6/15; Günalan-Sümbül (2013: 133).

9) BOA. DH. SN.THR. 18/62_1; Ekinci (2006:254).
} 


\section{THE ARCHITECTURAL AND CULTURAL CHARACTER OF POLONEZKÖY}

\section{Polonezköy Church And SchoOl}

According to some sources, the Church of Saint Anna, the first church in Polonezköy, was built between 1845 and 1846 and a new wooden church was built ${ }^{10)}$ between 1869 and $1870 .{ }^{11)}$ The renovation of the church in Polonezköy was discussed when Archbishop L. Rotelli, the representative of the Vatican in Istanbul, visited Polonezköy in 1883. The Archbishop donated a thousand francs for the renovation of the run-down church and Prince Czartoryski sent five hundred francs from France. ${ }^{12)}$ These endeavours probably did not yield any results. However, when the old church collapsed during the great earthquake of 1894 that affected Istanbul, the idea of building a new church, as well as a school, gained currency. ${ }^{13)}$ A document from January $15,1898,{ }^{14)}$ found in the Ottoman Archive of the Office of the Prime Minister, mentions stones that had been brought to Polonezköy for the construction of a church and school. However, the document also notes an investigation was required concerning possible disadvantages of such a construction for the area. Church and school construction plans fell through, presumably because necessary permissions could not be obtained.

Another file in the same archive includes correspondence on the Catholic Church and school planned in Polonezköy. ${ }^{15)}$ A petition dated September 15, 1909 (September 2, 1325 in the Rumi calendar), written to the Ministry of Justice and Religious Denominations (Adliye ve Mezahip Nezareti), was signed by Roman Biskupski, Ludwik Wilkoszewski, Jan Nowicki, and Wojciech Dochoda - who were members of the old families of Polonezköy (Appendix 3). The petition notes that the existing church in Polonezköy had been ruined by the earthquake and asks for a construction license for a new church, explaining that the church building would be between fifteen and twenty meters long and between nine and twelve meters wide, including

\footnotetext{
10) Adamska (2004:26).

11) Adamska (Undated).

12) Antonowicz-Bauer (1990:36).

13) Adamska (Undated); Antonowicz-Bauer (1990:36).

14) BOA. BEO. 1068/80093.

15) BOA. ŞD. 2383/5.
} 
priest's quarters. The petitioners stated they would pay the construction costs. ${ }^{16)}$

The aforementioned file includes information about the school the petitioners wanted outside the church. For instance, a document from October 19, 1913 (Teşrin-i Evvel [8th month] 6, 1329, in the Rumi calendar) ${ }^{17)}$ notes education had been provided in an old school building, and shows that were the school to be built along with the church, the cost would be eight hundred liras. The single-story building, seen in a photograph from 1910, must be the old school building of Polonezköy (Fig. 1).

A construction license was obtained for the new church and school at the end of 1913. ${ }^{18)}$ The church construction, including priest's quarters also used as a school, was completed in 1914 and devoted to the Virgin Mary of Czestochowa ${ }^{19)}$ (Figs 2a-b).

Polish architect N. Sliwinski designed the plan of the current church..$^{20}$ The construction license shows the church was to be twenty-two metres long, eight-and-a-half metres wide, ten-and-a-half metres high with a two metre high belfry on the roof. ${ }^{21)}$ The current church in Polonezköy is about twenty-two-and-a-half metres long, nine metres twenty-five centimetres wide and corresponds to the measurements specified in the license. A gable roof over a wooden vault covers the rectangular church, which is connected to the priest's quarters in the north side and the single-story sections, where religious objects were kept in the east side of the church (Figs 3a-b).

The entrance to the church, which was built on foundation walls as the slope of the land suggests, is on the west side of the church, which was designed more ornately than the other fronts, and the two-storey entrance plan inside, was projected on the outside. This front was divided in two by slim moulding, and the ground floor was plastered. The side walls appear to be made of bi-coloured stone slabs. The first floor encloses the roof space

16) According to some sources, the church was built in 1914 by the joint fund of donations Countess Zborowska collected abroad. See Antonowicz-Bauer (1990: 50).

17) BOA. ŞD. 2383/5.

18) BOA. ŞD. 2383/5;Günalan-Sümbül (2013: 221). Also see: BOA, BEO. 4276/320638; DH. İD. 162-2/27; MV. 232 / 104-1; Ekinci (2006: 257-258).

19) Antonowicz-Bauer (1990:36,53).

20) Antonowicz-Bauer (1990:36).

21) BOA. ŞD. 2383/5; Günalan-Sümbül (2013: 221); BOA. MV. 232/104-1; Ekinci (2006: 257-258). 
and was made to look like ashlar stone with straight grooves. The pillars in the corners balance the side walls downstairs, as well as the roof space. Putting vertical emphasis on the front, the faces of the pillars were animated with horseshoe-shaped niches and embossed patterns. There is a door and a window in the same axis in the middle section of the front. Bordered with composite columns, the double-leaf iron door has a slim canopy, which bears a Baroque-style arrangement, with a Latin cross in the middle, and highlights the entrance. The drop-arched window above was framed with distinct keystones (Figs 2b, 4).

The other fronts of the church are simple and in plain plaster. The singlestory section, adjacent to the middle of the abscissa front, is where religious objects were kept, connected to the abscissa niche inside. The enclosing belfry was renewed in 1986. As mentioned in the construction licence, there is a belfry in the middle of the roof (Fig. 3a).

Clergymen use the single-storey structure at the north front of the church. The aforementioned archive documents relates that the church was to be built with priest's quarters and a school. The measurements of the school were specified as ten metres long, ten metres wide and eight metres high. ${ }^{22}$ Its height suggests it could be a two-storey building. Old photos of the church show a two-storey building adjacent to the church, which was possibly the building planned as the school and priest's quarters. It was later converted to the current structure (Figs 2a, 3a).

As with the exterior, the interior of the church is rather simple. The twostorey entrance precedes the main entrance door to the west. The first floor consists of three sections and a suspended floor hangs above for the church organ. The plain walls were divided into six parts with plastered vertical bases. Apart from the abscissa and the entrance, one of the remaining four sections has a round arched window in the middle and the other three also have round arched niches in the centre. The main space of the church receives natural light from the other windows in the abscissa, and the entrance walls are round arched, except for the rose window on the abscissa niche (Fig. 3b).

The abscissa is the most embellished part of the interior of the church. The round-arched abscissa niche and long and narrow windows on its sides have been emphasized with a band of imitation-mosaic painting (Fig. 5a). the abscissa arch has also been decorated distinctly. The bottom surface of the arch is divided into rectangular and square sections, with wooden rosettes in

22) BOA. MV. 232/104-1; Ekinci (2006: 257). 
each square and oval patterns on blue background in the rectangles. Undoubtedly, the most striking aspect of the arrangement is the Polish inscription "POD TWOJA OBRONE UCIEKAMY SIE", which means "Beneath thy mercy we take refuge", on the surface of the arch. The horizontal bases of the entire wooden roof vault were divided into squares and rectangles, with wooden rosettes inside the squares (Fig. 3b).

The side wall cornices contribute to the decoration of the main space. The cornices, decorated with acanthus leaves, appear to have been made of plaster, but closer inspection shows they are made of wood. Likewise, a column capital of plaster, with imitation alabaster painting, was also made from wood (Fig. 5b).

\section{POLONEZKÖy CEMETERY ${ }^{23}$}

The village cemetery is one of the spaces that underline Polonezköy's history. The cemetery, the deeds of which currently belongs to Polonezköy, encompass 5740 square meters (Appendix 4, Fig. 6a).

The oldest graves were grouped in the middle and left of the cemetery. Most of these earthen graves do not have names. The first burial recorded by the church dates to June 26, 1848. Karol Zarzycki was buried in December 1850, Major Franciszek Michalowski in February 1851, Wladyslaw Jelenski in July $1851 .{ }^{24)}$ However, as the deceased did not have anyone to place tombstones, no trace of their graves survived.

Michal Czaykowski wanted Mickiewicz, the most important poet of Poland, who died in 1855 in Istanbul, to be buried in the village cemetery, but to no avail. However, Ludwika Śniadecka, the wife of Czaykowski, who died on February 22, 1866, in Istanbul, is buried here. This is the oldest grave with an epitaph in Adampol Cemetery. Sniadecka's marble tomb bears the coat of arms of Polish-Lithuanian Commonwealth (Poland, Lithuania, Ruthenia), and the Śniadecka and Czaykowski families. A thin column on the grave symbolizes an unfinished life (Fig. 6b). The inscription on the tombstone reads:

Ludwika of Sniadecki, daughter of faithful Jendrzej, niece of Jan, wife of the commander of Ottoman dragoons and Cossacks, died in Cihangir, Constantinople, on February 22, 1866. She was buried in the Polish land of Adamköy.

\footnotetext{
23) See: Adamska (undated).

24) Latka (1992: 34).
} 
The cemetery was first enclosed with walls in 1983. Conservation studies were completed in 1999. Signboards prepared in Warsaw were placed at the entrance to commemorate the unnamed people buried in the cemetery and the first colonists (Fig.6c).

\section{Examples of Civil Architecture}

The foundation of the first house in Polonezköy was consecrated with a ceremony on March 19, 1842. Leleu, the Archbishop of the Lazarists, and Michal Czaykowski, on behalf of the Prince, attended the ceremony. ${ }^{25}$

A very simple construction technique was used in the first houses built in Polonezköy. These were one-roomed houses, made of chestnut logs, directly on the ground, with no foundation walls. They had scanty furniture carved from wooden logs and accommodated both people and animals. ${ }^{26)}$ Village administrators managed the village until 1860 and a house was built in 1846 for the administration. The house was named 'the Mansion' and was the largest building of the village. ${ }^{27)}$ There were only 16 houses in the village in $1851 .{ }^{28}$

The number of houses in Polonezköy increased in time with the population. Houses were located on both sides of the road that crossed the village. ${ }^{29}$ A map in the Ottoman Archive in the Office of the Prime Minister, from the year 1338 in the Islamic calendar (1919-1920 in Gregorian calendar), shows the main layout plan of Polonezköy. ${ }^{30)}$ The map gives clues to the physical structure of the village during the foundation years; the red sections along both sides of two roads, one horizontal and one vertical, were presumably farm lands (Appendix 2, 5). Houses, and other outbuildings of the village, were probably located inside these farms.

Polish architectural traditions were applied to the houses built in Polonezköy. For instance, thatched roofs, which were prevalent in Polish countryside, were used in the village. These were built after the first wooden houses mentioned above, and point to a more technically advanced level of construction. These houses had a timberwork structure and their roofs sloped on four sides

\footnotetext{
25) Adamska (Undated).

26) Latka (1992: 34); Adamska (2004: 17).

27) Adamska (2004:5).

28) Antonowicz-Bauer (1990: 25).

29) Antonowicz-Bauer (1990: 33).

30) BOA. HRT. 0674.
} 
and were covered in thatch (Fig. 7a). They had rather small windows and the floorings were covered with earthenware tiles. As in Poland, white was the colour of choice for exterior and interior walls. Interior walls were painted with red clay up to half-a-metre in height. From the nineteen-thirties, tiles and metal plates started to be used on the roofs. The last examples of thatched roofs disappeared in the nineteen-seventies. ${ }^{31}$

Traditional Turkish houses were built in Polonezköy from the end of the 19th century. The first example of these houses was a hunting lodge built by the merchant Erben Nikititis around 1895. Jozef Dochoda acquired the lodge in 1931. Mustafa Kemal Atatürk stayed in the lodge in 1937, when he came to visit the village ${ }^{32)}$ (Fig. 7b). Another example of civil architecture in the village was the house of Zofia Rizi, built around the late 19th century. The house was restored and arranged as 'the Zofia Rizi Memorial House', on May 30, 2003 ${ }^{33)}$ (Fig. 8a-b).

\section{Police Station Building}

A further document found in the Ottoman Archive shows a decision was made to build a police station building on January $8,1905 .{ }^{34)}$ It is known there was an old police station in the area, but the building did not survive.

\section{CONCLUSION}

The residents of the village, which was an autonomous village founded for the citizens of a dismembered state, that had taken refuge in the Ottoman Empire, presumably had had the hope of founding an independent Polish State and returning to their country. Therefore, the initial residents of the village built simple structures for accommodation and social purposes, because they had to take on difficult tasks, such as having a forested area zoned for construction, and they thought they would probably return to their country. Unfortunately, these buildings did not survive. The historic architectural character that survived, was created in late 19th century and early 20th century, possibly as a result of changing living conditions, as well

\footnotetext{
31) Adamska (2004: 17-18).

32) Adamska (2004: 17-18).

33) See Adamska (2004).

34) BOA. İ. AS. 54/2; Günalan-Sümbül (2013: 137).
} 
as alterations in the legal structure of the village. As mentioned above, the land had been acquired from the Lazarists in the early eighteen-eighties and was made equal to other villages in terms of its rights and duties in the Period of the Second Constitution. Therefore, the village was no longer a base in the Ottoman Empire for the founding of an independent Polish State. Polonezköy became an Ottoman village with a Catholic Slavic population in the early 20th century and, as Ottoman documents indicate, public structures, such as a police station, were allowed in the village. The new church and school wanted in the village were subject to the same need for a Condition of Construction Licence laid down by the Empire for the religious and social buildings of other congregations.

The elements that reflect the history and identity of Polonezköy the best are the village cemetery and the church. Its historic character, divided by a road, provides for the needs of the new generation of Poles currently residing in the village. The single-nave church had a simple design, appropriate for the scale of a village church. It can be said that the imitation-mosaic interior painting and woodwork decorations were local solutions that minimized costs.

None of the first farmhouses in Polonezköy survived; but two of the few civil architectural structures that survived are both culturally significant. Zofia Rizi's house, which is located on the road that divided the church and the cemetery, is important in the way it summarizes Polonezköy's history. The single-storey house is located inside a garden, preserved with its original furniture, and conveys the previous lifestyle of the village. Some of the other few examples of civil architecture are used for tourism. For instance, Antony Dochoda's house, which was built in the late 19th century, currently functions as a restaurant.

Polonezköy is currently a popular spot for nature tourism, located close to Istanbul, and the village's existing historic character should be preserved.

\section{BIBLIOGRAPHY}

Adamska (undated) = Jolanta Adamska (ed.), Polonezköy Mezarlı̆̆ı.

Adamska (2004) = Jolanta Adamska (ed.), Polonezköy / Adampol Zofia Rızı Hatıra Evi, (Translation: Beata Uzunkaya), Warsaw 2004.

Antonowicz-Bauer (1990) = Lucyna Antonowicz-Bauer, Polonezköyü / Adampol, (Translation: Yeşim Santepe), Istanbul 1990. 
Biskupski (1955) = Ludwik Biskupski, “Un Coin Historique d'Istanbul: Polonezköy”, La Turquie Moderne, 103/Juin, Istanbul 1955: 38-19.

Dopierała (2014: 26-35)= Kazimierz Dopierała, "Osmanlı İmparatorluğu'nda ve Türkiye Cumhuriyeti'nde Polonyalılar", Uzak Komşu Yakın Anılar, Türkiye Polonya İlişkilerinin 600 Ylll, Istanbul 2014: 26-35.

Ekinci (2006) = Cevat Ekinci (ed.), Gök Kubbe Altında Birlikte Yaşamak, Belgelerin Diliyle Osmanlı Hoşgörüsü/ Living Together Under The Same Sky - The Land Of Tolerance: Ottoman, Ankara 2006.

Günalan-Sinan Sümbül (2013) = Rifat Günalan-Sinan Sümbül (ed.), Osmanlı Belgelerinde Beykoz, Istanbul 2013.

Łątka (undated) = Jerzy S. Łątka, Eski Fotoğraflarda Polonezköy (Adampol), (Translation: Antoni \& Nalan Sarkady), Istanbul.

Łątka (1992) = Jerzy S. Łątka, Polonezköy/Adampol, (Translation: Nalan\&Antony Sarkady), Istanbul 1992.

Documents

BOA.BEO. 1068/80093,

(Shaban 20, 1315 in the Islamic calendar / January 14, 1898 in Gregorian calendar).

BOA. BEO. 4276/320638,

(Jumada al-awwal 13, 1332 in the Islamic calendar / April 9, 1914 in Gregorian calendar). BOA. DH. MKT. 6/15,

(Rajab 4, 1310 in the Islamic calendar/ March 12, 1893 in Gregorian calendar).

BOA. DH. İD. 162-2/27,

(Jumada al-awwal 16, 1332 in the Islamic calendar / April 12, 1914 in Gregorian calendar). BOA. DH. SN.THR. 18/62_1,

(Safar 26, 1329 in the Islamic calendar/ February 26, 1911 in Gregorian calendar).

BOA. HRT. 0674,

(1338 in the Islamic calendar / 1919-1920 in Gregorian calendar).

BOA. HRT. 0676,

(1334 in the Islamic calendar / 1915-1916 in Gregorian calendar)

BOA. İ. AS. 54/2,

(Dhu al-Quidah 02, 1322 in the Islamic calendar / January 8, 1905 in Gregorian calendar). BOA. İ.DH. 1306/1311,

(Muharram ul Haram 5, 1311 in the Islamic calendar / July 19, 1893 in Gregorian calendar). BOA. MV. 232/104-1,

(Safar 16, 1332 in the Islamic calendar / Fanuary 4, 1914 in Gregorian calendar). BOA. ŞD. 2383/5,

(Muharram 21, 1332 in the Islamic calendar / December 20, 1913 in Gregorian calendar). 
[192]
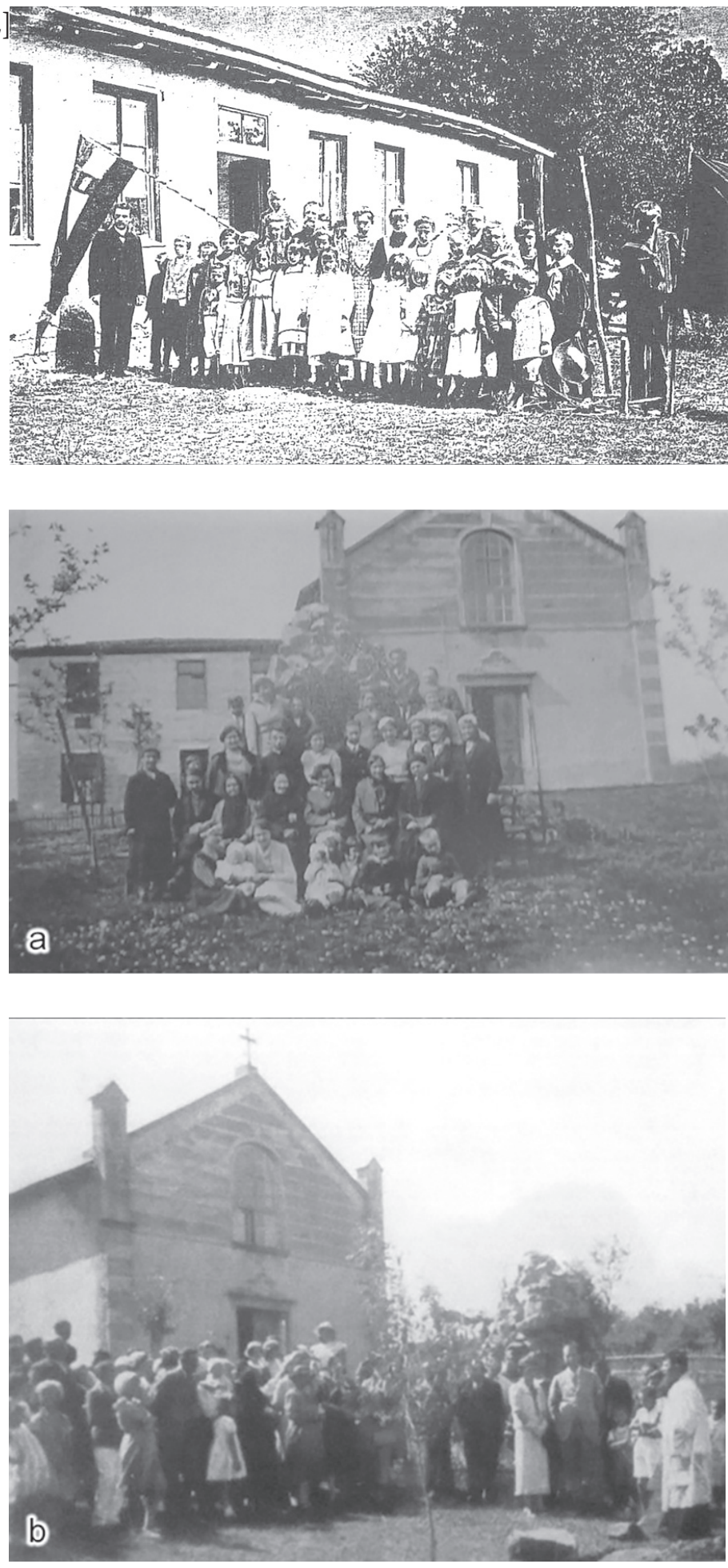

Fig. 1. The Old School Building of Polonezköy,(1910), Adamska (2004:25)

Fig. 2.a. The Catholic Church and School in Polonezköy, Latka (Undated:26)

Fig. 2.b. The

Catholic Church in Polonezköy, Adamska (2004:26) 

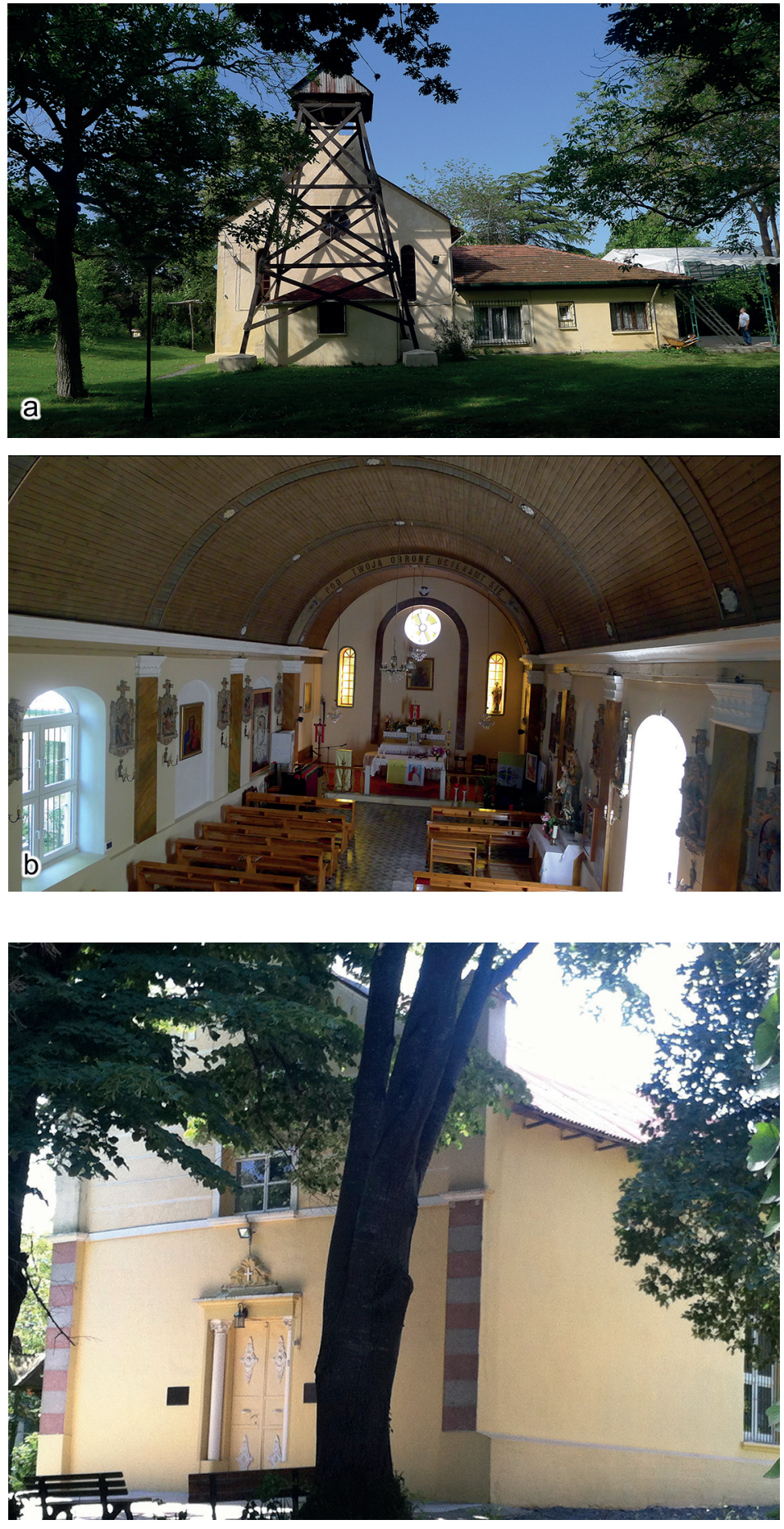

Fig. 3.a. The Catholic Church in Polonezköy (East Facade), (Phot. B. Demirsar Arlı, 2014)

Fig. 3. b. The Catholic Church in Polonezköy (Interior), (Phot. B. Demirsar Arlı, 2014)

Fig. 4. The Catholic Church in Polonezköy, (Entrance Facade), (Phot. B. Demirsar Arlı, 2014) 


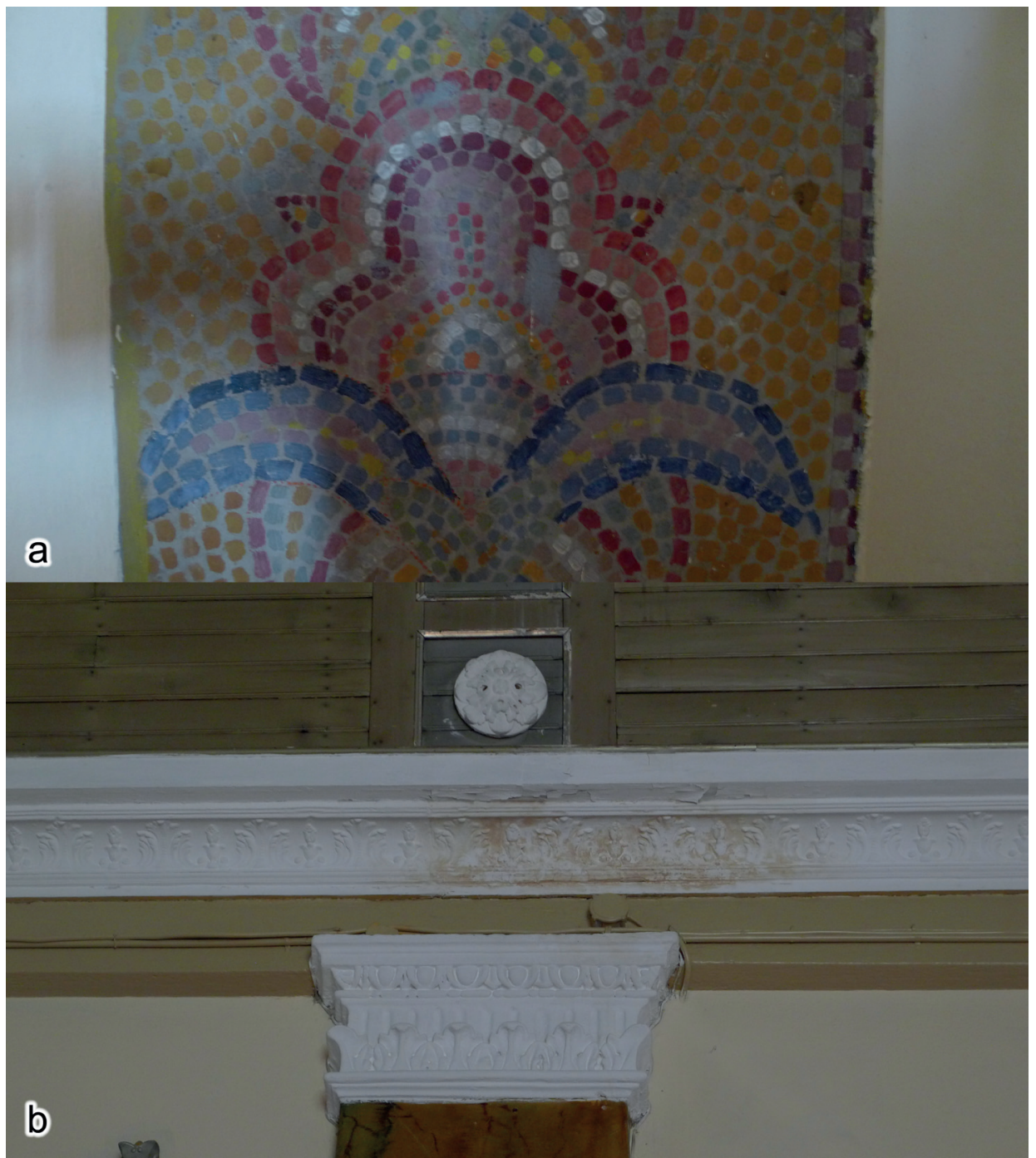

Fig. 5.a. The Detail of Mosaic-Imitation Painting, (Phot. B. Demirsar Arl1, 2014) Fig. 5.b. The Detail of Wooden Cornices and Column Capital, (Phot. B. Demirsar Arl, 2014) 

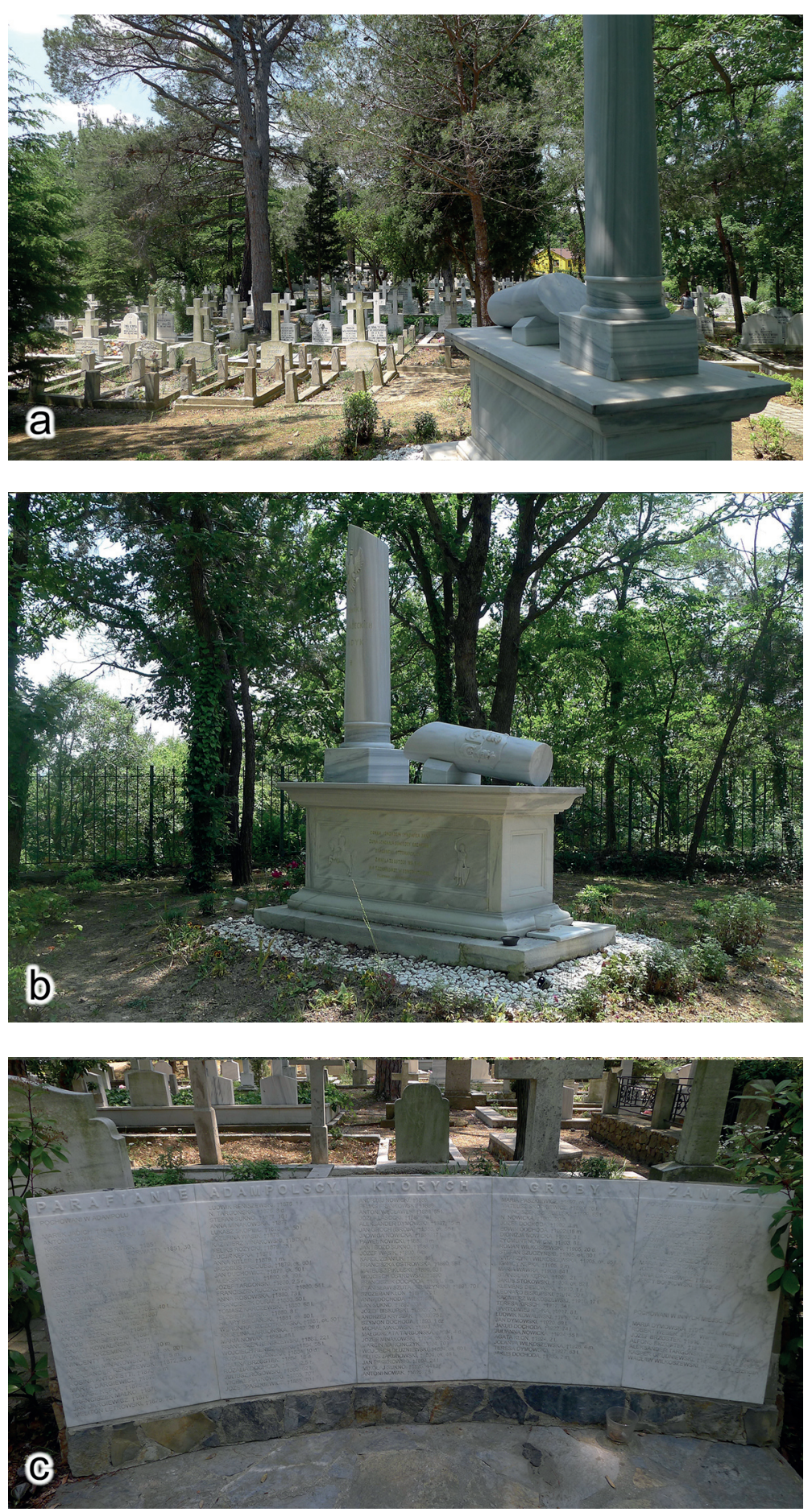

Fig. 6.a. Genaral View of Cemetery, (Phot.

B. Demirsar Arlı, 2014)

Fig. 6.b. The Ludwika Sniadecka's Tomb, (Phot.

B. Demirsar Arli, 2014)

Fig. 6.c. The

Signboard in the Entrance of Cemetery, (Phot. B. Demirsar Arlı, 2014) 

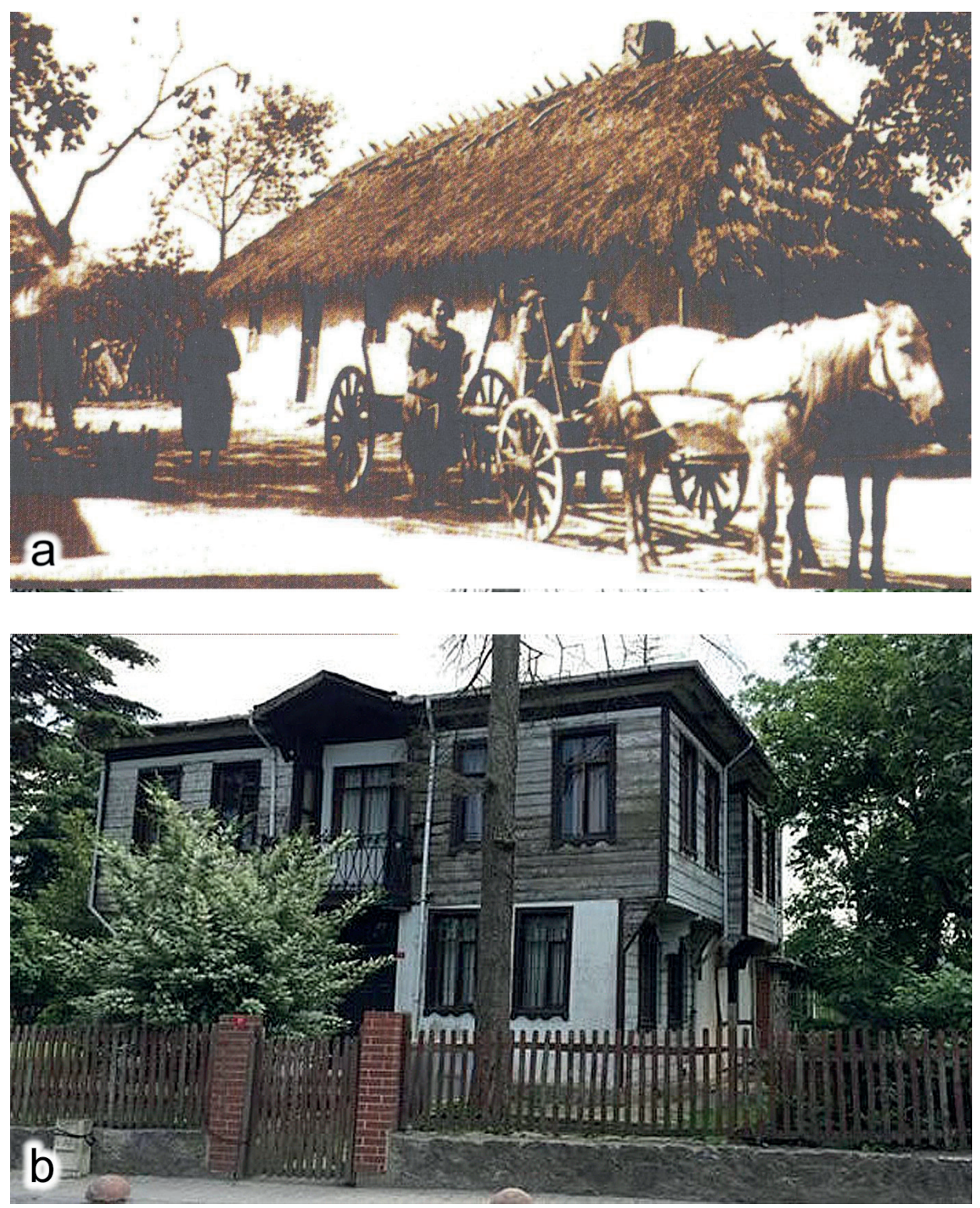

Fig. 7.a. The Example of thatch roof house in Polonezköy, Adamska, (2004:17)

Fig. 7.b. The Example of traditional houses, (Phot. B. Demirsar Arl, 2014) 

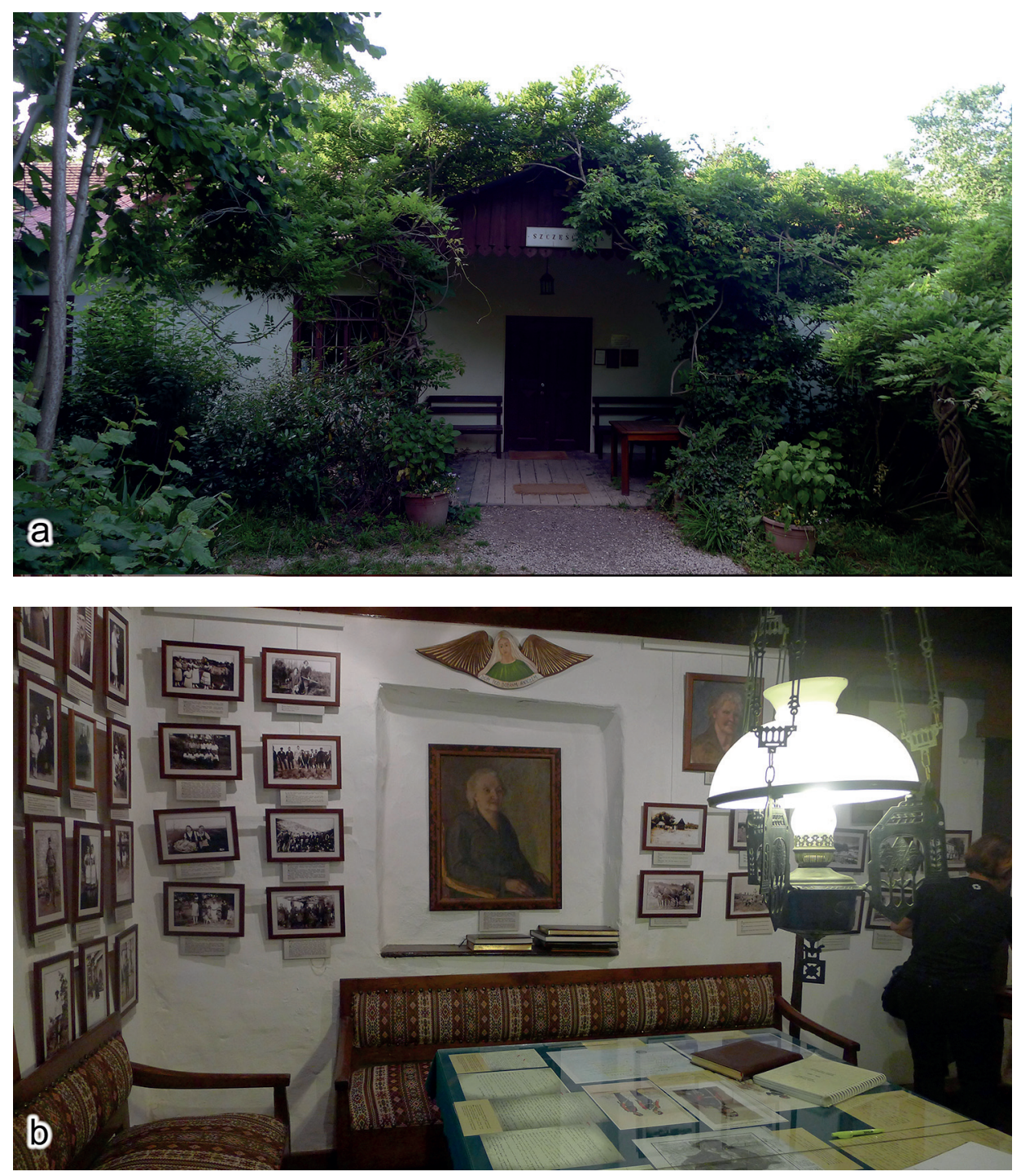

Fig. 8.a. Zofia Rizi Memorial House, (Phot. B. Demirsar Arl, 2014) Fig. 8.b. Zofia Rizi Memorial House, (Phot. B. Demirsar Arlı, 2014) 


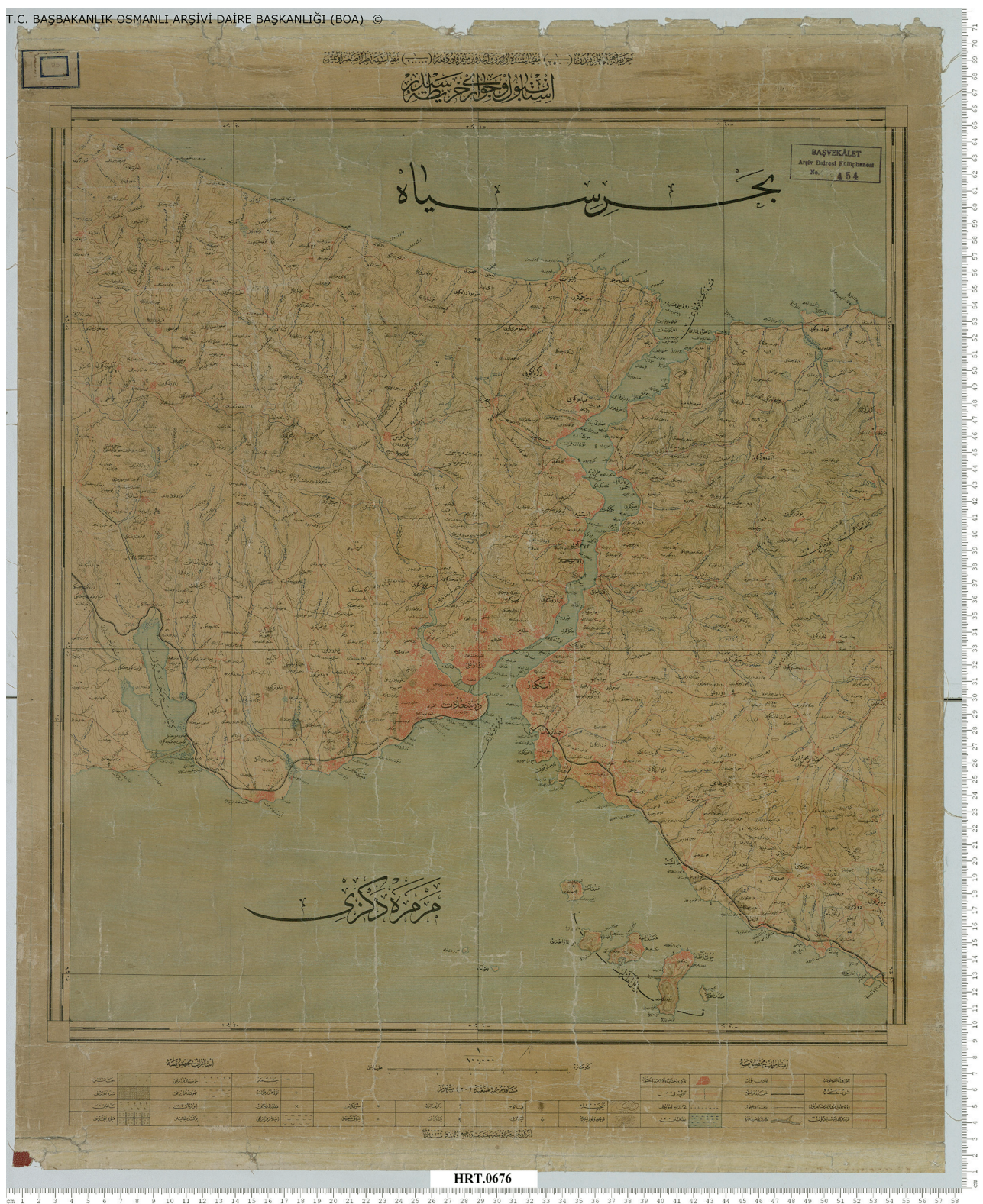

Appendix 1: The Map of Istanbul, (BOA. HRT.0676) 

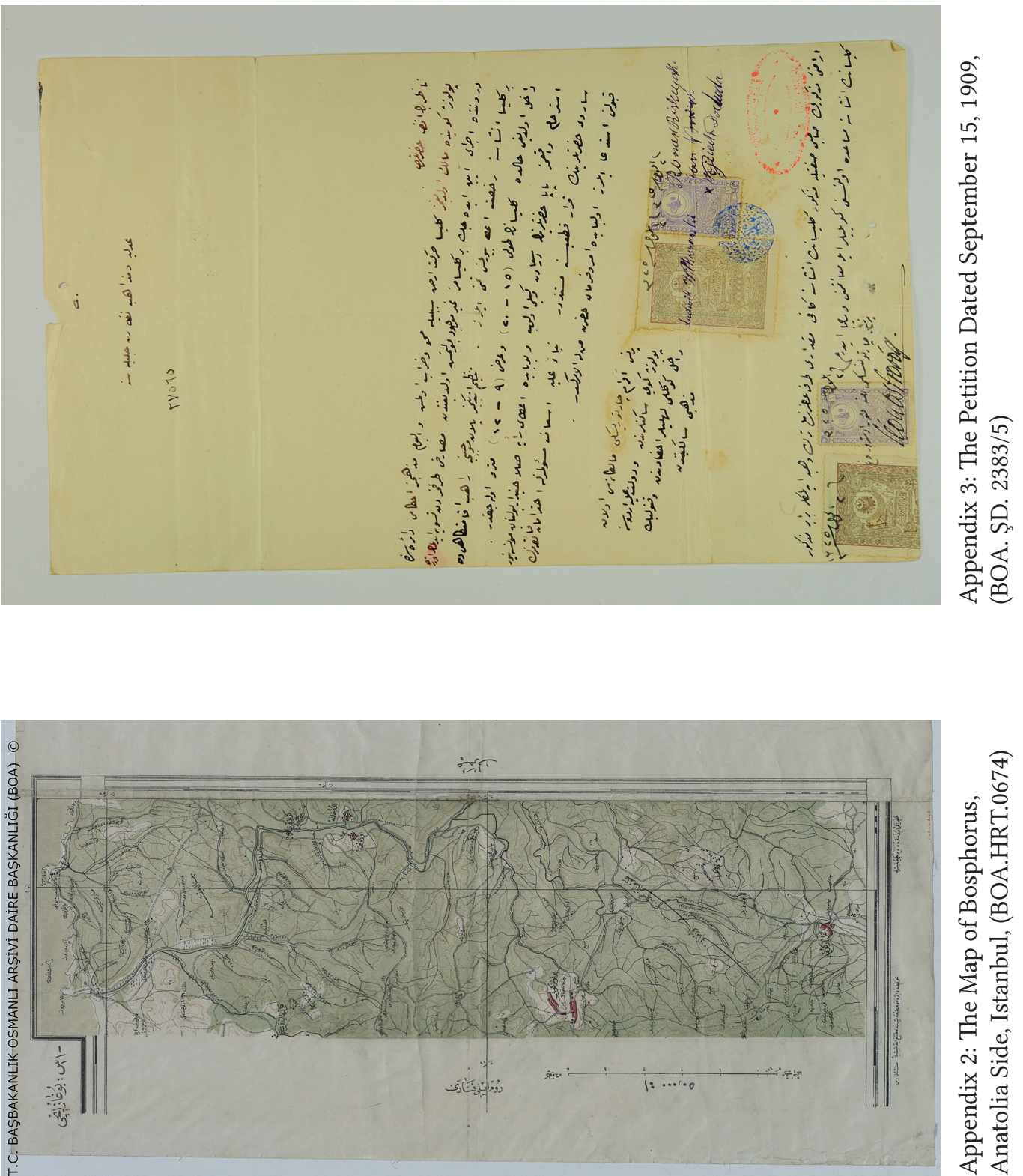